\title{
FRAKSI LARUT METANOL KULIT LIDAH BUAYA (Aloe vera) SEBAGAI LARVASIDA TERHADAP LARVA NYAMUK Aedes aegypti (Diptera: Culicidae)
}

\author{
Sari Rahmayanti ${ }^{1}$, Tri Baskoro T. Satoto ${ }^{2}$ \\ ${ }^{1}$ Departemen Parasitologi Fakultas Kedokteran \\ Universitas Tanjungpura, Pontianak \\ ${ }^{2}$ Departemen Parasitologi Fakultas Kedokteran, \\ Kesehatan Masyarakat dan Keperawatan \\ Universitas Gadjah Mada, Yogyakarta \\ Email korespondensi: \\ sari.rahmayanti@medical.untan.ac.id
}

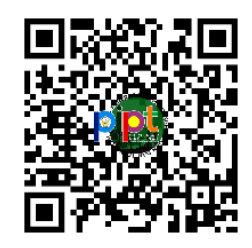

10.26418/pipt.2021.15

\begin{abstract}
Abstrak
Penyakit Demam Berdarah Dengue (DBD) merupakan penyakit infeksi yang ditularkan melalui gigitan nyamuk Aedes. Penggunaan insektisida sintetis jangka panjang dapat menimbulkan berbagai permasalahan, untuk meminimalisir permasalahan tersebut dapat digunakan larvasida botani yang merupakan insektisida yang bahan dasarnya berasal dari tumbuhan sebagai pengendali larva Aedes sp. Tanaman lidah buaya (Aloe vera) berpotensi sebagai larvasida. Aloe vera mengandung aloin yang berfungsi sebagai penyembuh luka, obat pencahar, antibakteri dan insektisida. Penelitian ini bertujuan untuk mengetahui pengaruh paparan fraksi larut metanol terhadap midgut larva Ae. aegypti. Penelitian ini merupakan penelitian eksperimental dengan rancangan post test only control group, dengan menggunakan analisis probit untuk menilai toksisitas. Hewan coba yang digunakan adalah Ae. aegypti instar III dengan 675 sampel larva, setiap perlakuan mengandung 25 larva dalam $100 \mathrm{ml}$ air. Penelitian dilakukan dengan sembilan perlakuan termasuk dosis yang digunakan adalah 10, 19, 36, 68.6, 130.3, 247.6 dan 500 bagian per juta (ppm), kontrol negatif (air dicampur pelarut tween $800.15 \%$ ) dan kontrol positif (Temephos 0,02 ppm) dengan waktu pengamatan 24 jam. Kandungan aloin dalam fraksi terlarut metanol diidentifikasi dengan Kromatografi Lapis Tipis (KLT). Identifikasi kerusakan midgut larva Ae.aegypti diperiksa secara mikroskopis. Uji larvasida fraksi larut metanol menghasilkan nilai $\mathrm{LC}_{50} 120.56$ ppm dan $\mathrm{LC}_{90} 875.2 \mathrm{ppm}$. Fraksi larut metanol kulit lidah buaya menyebabkan kerusakan morfologi organ midgut larva Ae. aegypti di daerah membran peritrofik dan mikrovili. Semakin tinggi dosis fraksi larut metanol, kerusakan yang terjadi semakin parah.
\end{abstract}

Kata kunci: Aedes aegypti, larvasida, aloin, fraksi larut metanol, kulit lidah buaya

\section{PENDAHULUAN}

Nyamuk Aedes aegypti merupakan vektor utama penyakit Demam Berdarah Dengue (DBD) yang menularkan virus dengue melalui gigitannya pada manusia. Penyakit DBD diperkirakan menginfeksi 50100 juta orang setiap tahunnya dan terjadi hampir pada separuh populasi dunia yang tinggal di negara-negara endemik demam berdarah (WHO, 2014). Tahun 2016 telah dilaporkan sebanyak 204.171 kasus DBD tersebar di Indonesia dan 1.598 orang diantaranya meninggal (Kemenkes, 2018).

Pengendalian vektor secara kimiawi sampai saat ini masih sering dilakukan masyarakat dibandingkan pengendalian secara biologis. Hal ini karena insektisida sintetis dianggap lebih efektif dan hasilnya cepat terlihat. Temefos adalah cara kimiawi yang sering digunakan di masyarakat. Penggunaan insektisida sintetis jangka panjang, khususnya larvasida dapat menimbulkan efek, antara lain resistensi terhadap serangga, pencemaran lingkungan dan residu insektisida (Zhu, 2008).

Penggunaan larvasida botani dapat digunakan sebagai pengendali larva Aedes sp. Tanaman A. vera memiliki potensi sebagai larvasida dan telah dikenal masyarakat sebagai tumbuhan obat (Maurya, et al., 2008). Lateks $A$. vera banyak mengandung antrakuinon atau senyawa fenolik (aloesin, aloin dan emodin) dan glikosida yang 
memiliki efek laksatif yang kuat, bertindak sebagai antibakteri, analgetik dan antivirus. Berbagai aktivitas biologis ini karena kandungan aloin yang banyak ditemukan pada lapisan berwarna kuning, yang terletak di antara kulit dan daging daun serta sedikit pada daging daun $A$. vera yang sering dikaitkan sebagai penyembuh luka, antimalaria, antibakteri, antijamur, antiparasit, obat pencahar, obat luka bakar dan insektisida (Kumar dan Yadav, 2014).

Penelitian ini untuk mengetahui efek larvasida dan pengaruh paparan fraksi larut metanol terhadap membran peritrofik dan mikrovili abdomen larva Ae. aegypti. Pengamatan dilakukan menggunakan mikroskop yang disambungkan dengan lensa Optilab.

\section{BAHAN DAN METODE}

\section{Persiapan ekstrak tanaman}

Bagian tanaman yang digunakan adalah kulitnya. Kulit tanaman diambil yang berumur 10-12 bulan. Kulit Aloe vera yang diperoleh dicuci bersih sebelum dipisahkan dari gelnya dan beratnya $10 \mathrm{~kg}$ kemudian dikeringkan pada suhu $50^{\circ} \mathrm{C}$. Simplisia kering diserbukkan dengan blender dan disimpan dalam wadah tertutup.

\section{Pembuatan fraksinasi lidah buaya}

Sejumlah 700 g serbuk kulit Aloe vera dimaserasi dengan 1 liter pelarut kloroform selama 24 jam. Ekstrak disaring melalui corong Buchner dengan kertas saring Whatman dan dilakukan pengulangan sebanyak dua kali kemudian disaring. Filtrat yang didapat digabung dan diuapkan sampai kering, sehingga diperoleh ekstrak kloroform kental, kemudian ditimbang untuk mengetahui rendemennya.

Ekstrak kloroform selanjutnya difraksinasi menggunakan metanol dengan diaduk perlahan hingga didapatkan hasil partisi larut metanol menjadi jernih. Cairan larut metanol dimasukkan ke dalam tabung reaksi kemudian disentrifus pada $5000 \mathrm{rpm}$ selama 10 menit, sehingga diperoleh dua fraksi, yaitu fraksi larut metanol dan tidak larut metanol. Keberhasilan penyarian dimonitor dengan metode Kromatografi Lapis Tipis (KLT), yang diperoleh dalam bentuk bercak warna.

\section{Uji larvasida fraksi larut metanol}

Tujuh variasi dosis diperoleh setelah dilakukan uji pendahuluan sebelumnya. Adapun dosis tersebut $10 ; 19 ; 36 ; 68.6$; 130.3; 247.6 dan 500 ppm. Kontrol negatif yang berisi aqua destilata dicampur pelarut tween $800.15 \%$ disertakan dalam penelitian tersebut. Kontrol positif menggunakan Temefos 0,02 ppm. Setiap kelompok uji dilakukan tiga kali pengulangan dan mengandung 25 larva Ae. aegypti instar III di setiap wadah yang berisi $100 \mathrm{ml}$ air (WHO, 2005).

Pengujian dilakukan pada suhu kamar dengan suhu air yang terkontrol. Selama pengujian larva tidak diberi makan. Setelah 24 jam pemberian fraksi larut metanol kulit Aloe vera, dilakukan pengamatan dan pencatatan larva yang mati pada tiap larutan. Larva dinyatakan mati apabila tenggelam atau tidak bergerak setelah disentuh dengan pipet pada sifon atau daerah thoraks (WHO, 2005). Penelitian ini merupakan penelitian eksperimental dengan rancangan post test only control group yang menggunakan analisis probit untuk menilai toksisitas.

\section{Identifikasi kerusakan abdomen larva $A e$. aegypti}

Larva diletakkan di kaca objek ditetesi dengan reagen hoyers, ditutup dengan kaca penutup dan didiamkan beberapa hari sampai mengering. Preparat diamati dengan mikroskop yang disambungkan dengan lensa Optilab dengan perbesaran 4x10. Kerusakan membran peritrofik dan mikrovili abdomen larva Ae. aegypti berupa penebalan pada membran peritrofik (nekrosis difus) dan nekrosis pada permukaan mikrovili (erosi difus).

\section{HASIL DAN PEMBAHASAN}

\section{Aloin pada fraksinasi larut metanol kulit lidah buaya}


Hasil KLT fraksi larut metanol dapat dilihat pada Gambar 1.

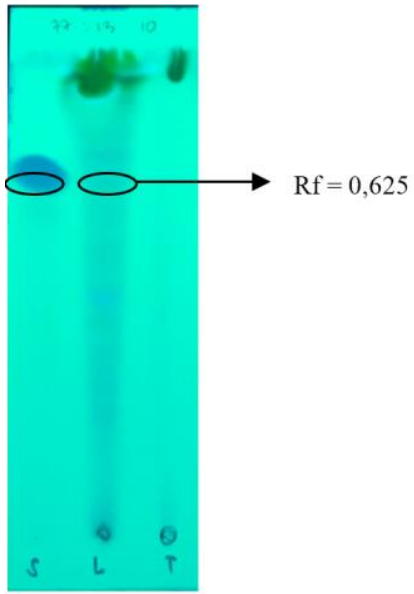

I

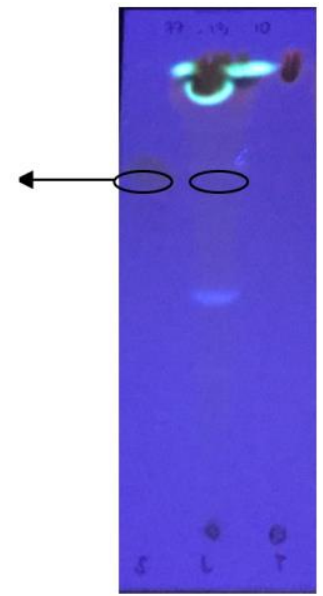

II
Gambar 1: Kromatogram KLT (I) Fraksi larut metanol pada $\mathrm{UV}_{254}$ (II) Fraksi larut metanol pada $\mathrm{UV}_{366}$ (S: Aloin, L: Larut metanol, T: Tidak larut metanol)

Kromatografi Lapis Tipis ini menggunakan fase gerak etil asetat, metanol, aquades (77:13:10). Hasil uji KLT pada Gambar 1 memberikan informasi bahwa fraksi larut metanol menunjukkan bercak warna yang sama dengan standar aloin, yang artinya fraksi larut metanol mengandung senyawa aktif aloin dengan nilai Retention factor $(\mathrm{Rf})=0,625$ baik dideteksi dengan sinar $\mathrm{UV}_{254}$ maupun $\mathrm{UV}_{366}$, sedangkan fraksi tidak larut metanol tidak memiliki bercak. Nilai Rf yang sama antara fraksi larut metanol dari ekstrak kloroform dengan aloin dapat dikatakan bahwa senyawa tersebut memiliki karakteristik yang sama.

\section{Efek larvasida fraksi larut metanol kulit lidah buaya}

Hasil uji aktivitas larvasida fraksi larut metanol kulit $A$. vera terhadap larva $A e$. aegypti ditampilkan pada Tabel 1.

Tabel 1: Efek larvasida fraksi larut metanol kulit $A$. vera terhadap larva Ae. aegypti instar III

\begin{tabular}{|c|c|c|c|c|c|}
\hline $\begin{array}{c}\text { Dosi } \\
\text { s } \\
(\mathrm{ppm} \\
\text { ) }\end{array}$ & $\begin{array}{c}\text { Jumla } \\
\text { h } \\
\text { larva }\end{array}$ & $\begin{array}{l}\text { Mortalita } \\
\text { s Larva } \\
\text { (mean } \pm \\
\text { SD)* }\end{array}$ & $(\%)$ & $\begin{array}{c}\text { Nilai } \\
\text { LC }_{50} \\
24 \text { jam }\end{array}$ & $\begin{array}{c}\text { Nilai } \\
\text { LC }_{90} \\
24 \text { jam }\end{array}$ \\
\hline 10 & 25 & $\begin{array}{l}2,33 \\
0,58\end{array}$ & 9,33 & & \\
\hline
\end{tabular}

\begin{tabular}{|c|c|c|c|c|c|c|}
\hline 19 & 25 & $\begin{array}{l}3,00 \\
1,00\end{array}$ & \pm & 12 & $\begin{array}{l}120,56 \\
\mathrm{ppm}^{* *}\end{array}$ & $\begin{array}{c}875,2 \\
\text { ppm }\end{array}$ \\
\hline 36 & 25 & $\begin{array}{l}5,67 \\
1,53\end{array}$ & \pm & $\begin{array}{l}22,6 \\
7\end{array}$ & $\begin{array}{c}(89,8- \\
161,85\end{array}$ & $\begin{array}{l}(464,2- \\
1650,15\end{array}$ \\
\hline 68.6 & 25 & $\begin{array}{l}9,00 \pm \\
1,00\end{array}$ & & 36 & ) & ) \\
\hline $\begin{array}{l}130 . \\
3\end{array}$ & 25 & $\begin{array}{l}10,33 \pm \\
2,31\end{array}$ & & $\begin{array}{l}41,3 \\
3\end{array}$ & & \\
\hline $\begin{array}{l}247 . \\
6\end{array}$ & 25 & $\begin{array}{l}15,33 \\
2,08\end{array}$ & \pm & $\begin{array}{l}61,3 \\
3\end{array}$ & & \\
\hline 500 & 25 & $\begin{array}{l}23,00 \\
1,00\end{array}$ & \pm & 92 & & \\
\hline $\mathrm{K}(-)$ & 25 & $\begin{array}{l}0,00 \\
0,00\end{array}$ & \pm & 0 & & \\
\hline $\mathrm{K}(+)$ & 25 & $\begin{array}{l}25,00 \\
0,00\end{array}$ & \pm & 100 & & \\
\hline
\end{tabular}

Keterangan: K (+): Temefos 0,02 ppm; K (-): Aquades dicampur tween $800.15 \%$; *nilai rata-rata tiga kali replikasi; **confidence limit $95 \%$

Hasil perhitungan analisis probit aktivitas larvasida dengan bahan uji fraksi larut metanol kulit $A$. vera pada Tabel 1, menunjukkan semakin tinggi dosis fraksi larut metanol kulit $A$. vera, semakin besar persentase mortalitas larva Ae. aegypti. Nilai $\mathrm{LC}_{50} 120.56$ ppm yang berarti pada dosis tersebut dapat menimbulkan kematian larva Ae. aegypti sebanyak 50\%. Nilai LC 90875.2 ppm memberikan kematian $90 \%$.

Nilai $\mathrm{LC}_{50}$ dan $\mathrm{LC}_{90}$ dipengaruhi oleh sifat kepolaran pelarut. Metanol bersifat polar sehingga dapat menarik senyawa aloin, karena secara uji kuantitatif aloin dapat larut dalam pelarut polar (Nagaraju, 2011). LC $_{50}$ fraksi larut metanol terhadap larva $A e$. aegypti instar III memberikan dosis yang lebih kecil dibandingkan dengan penelitian Subramaniam et al. (2012) LC 50 ekstrak petroleum eter lidah buaya, yaitu 253.33 ppm. Ini menunjukkan bahwa fraksi larut metanol kulit lidah buaya lebih potensial untuk membunuh larva uji 50\%.

\section{Pengamatan kerusakan abdomen larva Ae. aegypti akibat paparan fraksi larut metanol kulit $A$. vera}

Pengamatan secara mikroskopis dilakukan terhadap larva yang telah dipapar fraksi larut metanol kulit A. vera selama 24 jam untuk mengetahui kerusakan yang terjadi. Efek paparan fraksi larut metanol terhadap kerusakan abdominal larva $A e$. aegypti instar III ditampilkan pada Tabel 2. 
Tabel 2. Efek paparan fraksi larut metanol terhadap kerusakan abdominal larva Ae. aegypti instar III

\begin{tabular}{ccc}
\hline $\begin{array}{c}\text { Dosis } \\
(\mathrm{ppm})\end{array}$ & $\begin{array}{c}\text { Kerusakan } \\
\text { Membran } \\
\text { Peritrofik }\end{array}$ & $\begin{array}{c}\text { Kerusakan } \\
\text { Saluran } \\
\text { Pencernaan }\end{array}$ \\
\hline 10 & $0(24 \%)$, & $0(32 \%)$, \\
& $1^{+}(76 \%)$ & $1^{+}(68 \%)$ \\
19 & $0(12 \%)$ & $0(16 \%)$, \\
& $1^{+}(88 \%)$ & $1^{+}(84 \%)$ \\
36 & $1^{+}(28 \%)$, & $2^{+}(100 \%)$ \\
& $2^{+}(72 \%)$ & \\
68.6 & $2^{+}(100 \%)$ & $2^{+}(72 \%)$, \\
& & $3^{+}(28 \%)$ \\
130.3 & $2^{+}(44 \%)$, & $2^{+}(60 \%)$, \\
& $3^{+}(56 \%)$ & $3^{+}(40 \%)$ \\
& $3^{+}(100 \%)$ & $3^{+}(36 \%)$, \\
500 & $3^{+}(40 \%)$, & $4^{+}(64 \%)$ \\
& $4^{+}(60 \%)$ & \\
$\mathrm{K}(-)$ & $0(100 \%)$ & $0(100 \%)$ \\
$\mathrm{K}(+)$ & $4^{+}(100 \%)$ & $4^{+}(100 \%)$ \\
\hline
\end{tabular}

Keterangan: K (+): Temefos 0,02 ppm; K (-): Aquades dicampur Tween $800.15 \% ; 0=0 \%$ nekrosis; $1^{+}=1-$ $25 \%$ nekrosis; $2^{+}=26-50 \%$ nekrosis; $3^{+}=51-75 \%$ nekrosis; $4^{+}=>76 \%$ nekrosis (Murini, 2017)

Hasil pengamatan morfologi larva $A e$. aegypti instar III setelah pemberian fraksi larut metanol kulit $A$. vera selama 24 jam dan temefos 0,02 ppm menunjukkan adanya perbedaan dibandingkan dengan kontrol negatif (aquades dicampur tween 80 0.15\%). Larva Ae. aegypti instar III kontrol negatif tidak menunjukkan adanya kerusakan pada bagian tubuhnya (Gambar 2), sedangkan pada larva yang diberi fraksi larut metanol kulit $A$. vera berbagai dosis menunjukkan adanya kerusakan pada bagian midgut. Semakin tinggi dosis yang diberikan, tingkat kerusakan yang timbul pada organ midgut juga semakin parah (Gambar 2-10). Rusaknya MP menyebabkan mikrovili yang menempel pada membran basalis ikut rusak

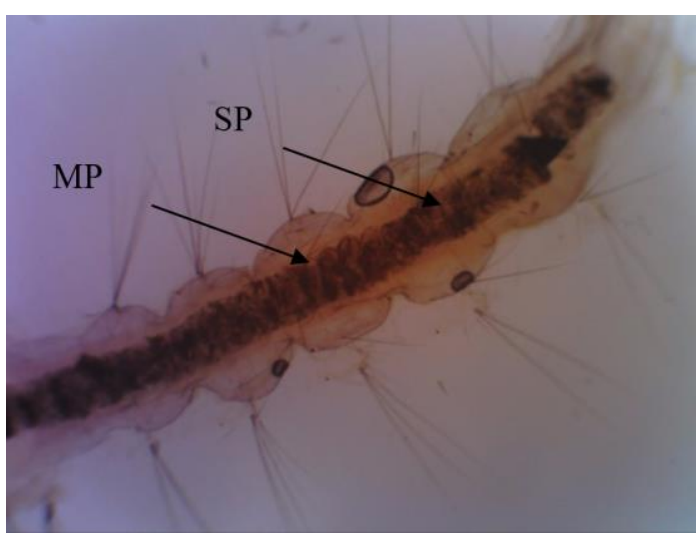

Gambar 2: Larva Ae. aegypti instar III kontrol negatif. Membran peritrofik (MP) dan saluran pencernaan (SP) dengan perbesaran $4 \times 10$

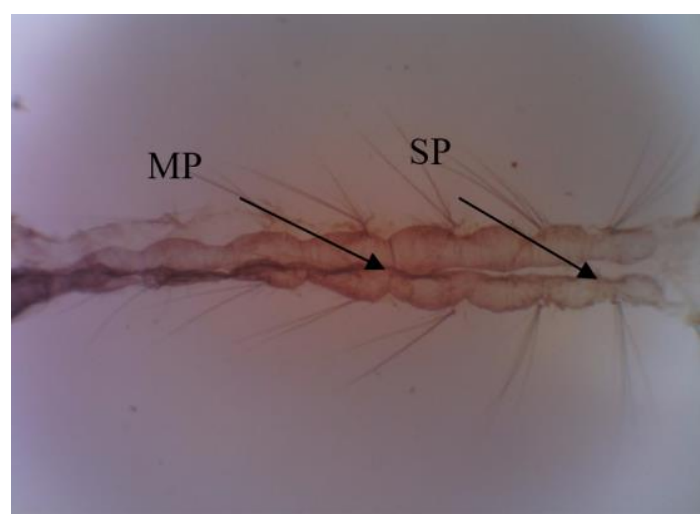

Gambar 3: Larva Ae. aegypti instar III setelah dipapar fraksi larut metanol kulit A. Vera dosis 10 ppm. MP tampak mengalami nekrosis dan SP menyempit

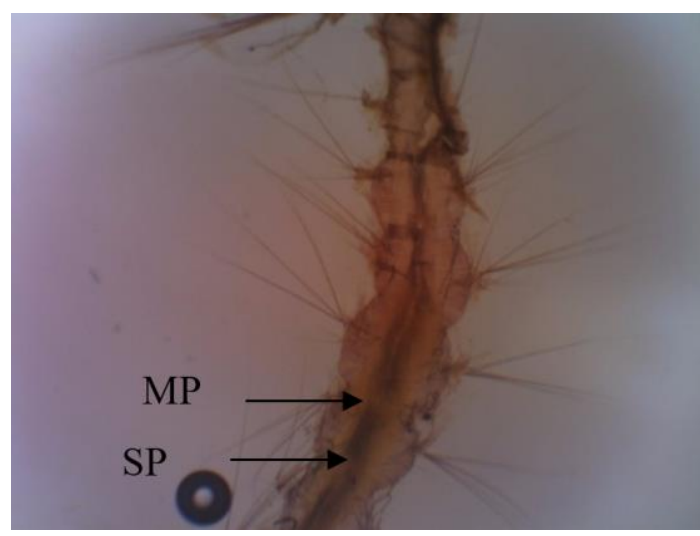

Gambar 4: Larva Ae. aegypti instar III setelah dipapar fraksi larut metanol kulit A. vera dosis 19 ppm. MP tampak mengalami nekrosis dan SP menyempit 


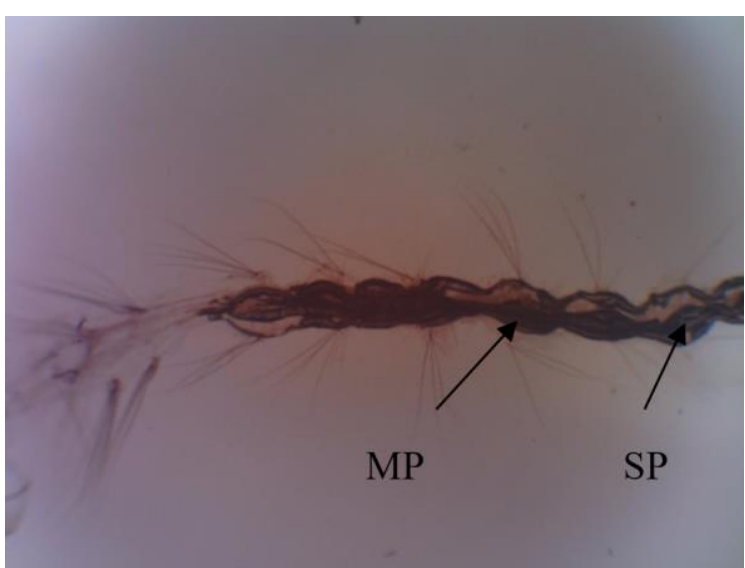

Gambar 5: Larva Ae. aegypti instar III setelah dipapar fraksi larut metanol kulit A. vera dosis 36 ppm. MP tampak mengalami nekrosis dan SP menyempit serta menyatu dengan MP

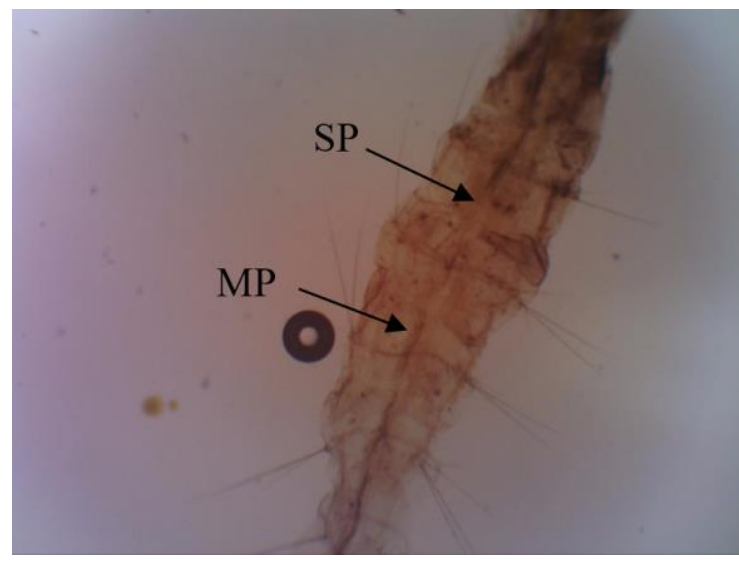

Gambar 6: Larva Ae. aegypti instar III setelah dipapar fraksi larut metanol kulit A. Vera dosis 68.6 ppm. MP tampak mengalami nekrosis, SP menyempit dan menyatu dengan MP

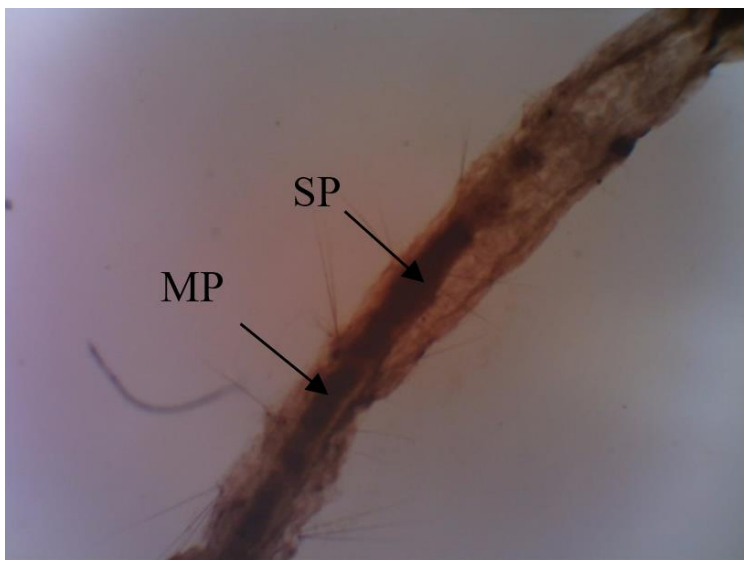

Gambar 7: Larva Ae. aegypti instar III setelah dipapar fraksi larut metanol kulit $A$. vera dosis 130.3 ppm. MP mengalami nekrosis, SP menyempit, memendek dan bergeser dari posisi seharusnya serta menyatu dengan MP

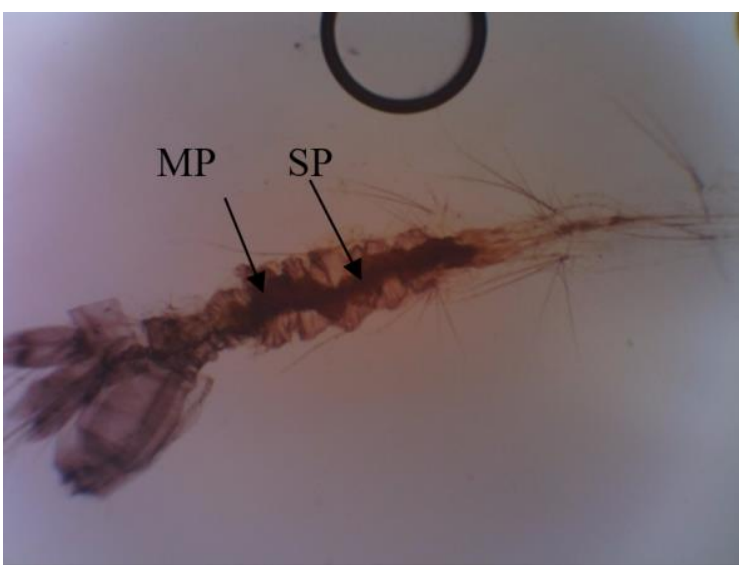

Gambar 8: Larva Ae. aegypti instar III setelah dipapar fraksi larut metanol kulit A. vera dosis 247.6 ppm. MP mengalami nekrosis, SP menyempit, memendek dan bergeser dari posisi seharusnya serta menyatu dengan MP

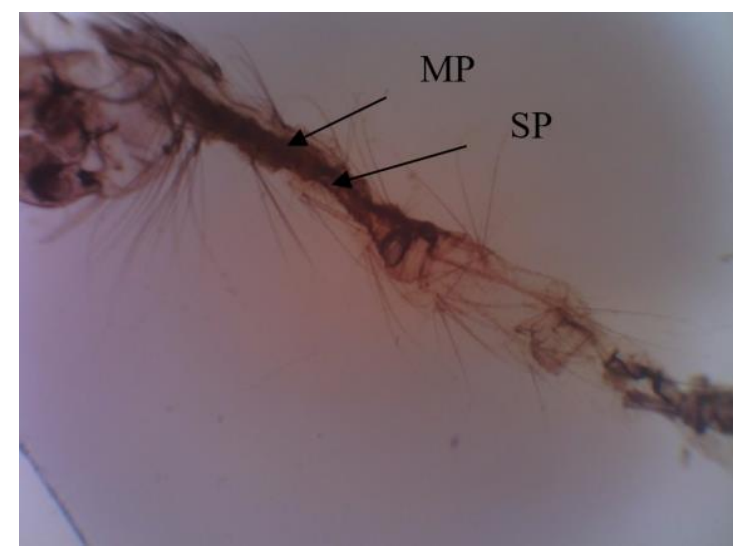

Gambar 9: Larva Ae. aegypti instar III setelah dipapar fraksi larut metanol kulit A. vera dosis 500 ppm. MP mengalami nekrosis dan SP menyempit, memendek dan bergeser dari posisi seharusnya serta menyatu dengan MP, Setae tampak tidak beraturan

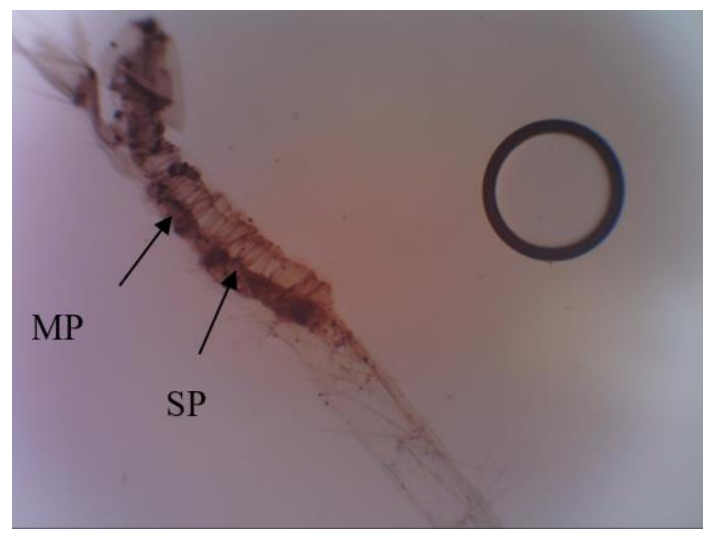

Gambar 10: Larva Ae. aegypti instar III kontrol positif dengan temefos 0,02 ppm. MP tampak mengalami nekrosis dan SP menyempit, memendek dan bergeser dari posisi seharusnya serta menyatu dengan PM, Setae tampak rusak 
Pemberian temefos 0,02 ppm pada larva Ae. aegypti instar III menyebabkan munculnya warna kehitaman pada midgut, MP mengalami nekrosis difus dan setae tampak rusak. Ukuran tubuh larva dengan perlakuan temefos $0,02 \mathrm{ppm}$ dan fraksi larut metanol dengan dosis 247,6 ppm dan 500 ppm lebih kecil dibandingkan dengan kontrol negatif. Berdasarkan hasil pengamatan mikroskopis optilab dengan perbesaran $4 \times 10$ pada semua dosis uji, larva Ae. aegypti yang dipapar didapatkan kerusakan pada bagian usus tengah (midgut) pada daerah membran peritrofik dan mikrovili.

Paparan fraksi larut metanol kulit A. vera rata-rata menimbulkan kerusakan pada bagian usus tengah larva (midgut). Midgut terdiri dari empat jenis sel dalam lapisan epitel tunggal yang mencakup sel kolumnar, sel regeneratif sel goblet dan sel endokrin. Sel kolumnar merupakan sel-sel utama yang paling banyak dengan batas-batas yang menghadap lumen yang mengandung mikrovili yang melimpah dan banyak lipatan yang berfungsi meningkatkan luas permukaan untuk penyerapan dan sekresi. Sebagian besar nutrisi dalam lumen usus diserap melalui sel-sel kolumnar ini. Sel-sel yang membentuk midgut rentan terhadap abrasi oleh makanan karena tidak memiliki lapisan kutikula. Sel midgut pada larva nyamuk menghasilkan membran peritrofik yang terdiri dari jaringan mikrofibin kitin dalam matrik karbohidrat dan protein. Membran peritrofik memiliki peran penting dalam pembentukan kompartemen untuk pencernaan dan membantu dalam mempertahankan aliran air berlawanan yang menghasilkan gerakan zat terlarut dalam usus dan kompartementalisasi enzim dan produk pencernaan. Membran peritrofik mengandung pori-pori dan permeabel untuk beberapa enzim pencernaan dan produk pencernaan (Klowden, 2007). Rusaknya membran peritrofik larva memengaruhi persediaan makanan, jika asupan makanan yang diserap berkurang maka akan menyebabkan kematian.

Beberapa peneliti menunjukkan bahwa larvasida menyebabkan kerusakan morfologis pada membran peritrofik dimana zat itu diserap. Adanya sel epitel yang menonjol ke dalam lumen mengakibatkan membran peritrofik rusak. Lisis di midgut berkembang melalui sel-sel yang bengkak sehingga terjadi vakuolisasi. Membran basal yang mendasari sel epitel melebar dihampir semua di sekitar midgut setelah diberi fraksi larut metanol kulit A. vera, yang berakibat rusaknya mikrovili. Midgut merupakan saluran gastrointestinal yang terdiri dari membran basal, sel epitel, mikrovili, membran peritrofik dan lumen. Nekrosis yang terjadi pada sel epitel mengakibatkan berkurangnya ketegangan permukaan pada organ midgut sehingga dapat menghambat fungsi pencernaan dan penyerapan makanan yang berakibat kematian larva. Mikrovili merupakan tempat absorpsi dan menggerakkan bolus makanan (Clements, 1992; Begum, 2016).

Daerah perut serangga, selain berfungsi untuk pencernaan, juga memberikan fungsi pertahanan kimia, perlindungan mekanik dan pertahanan terhadap patogen. Saat organ pencernaan (midgut) mengalami nekrosis, maka fungsi sebagai pertahanan terhadap bahan kimia, mekanik dan patogen akan hilang yang berakibat kematian larva. Permukaan tubuh larva menyerap senyawa biotoksik dalam jumlah banyak dan dapat dengan mudah menembus kutikula (Lu dan Kacew, 2002; Scudeler et al., 2014). Dinding tubuh serangga merupakan kutikula yang bersifat hidrofobik dan lipofilik, sehingga senyawa yang bersifat semipolar dengan mudah menembus masuk ke dalam tubuh larva. Kerusakan itu terjadi karena hilangnya kontrol keseimbangan antara ion dan asupan air yang pada umumnya pemberiannya dengan minyak, ekstrak tumbuhan dan racun, terlepas dari jenis bahan nabati maupun kimia yang digunakan, kesamaan perubahan tersebut merupakan respon umum terhadap keracunan seluler (Salvador et al., 2016).

Pelarut metanol sama seperti pelarut kloroform yang dapat menarik senyawa aktif seperti flavonoid, saponin, alkaloid, steroid, antrakuinon dan triterpenoid. Senyawa saponin dan antrakuinon menyebabkan 
kerusakan membran sitoplasma dan kematian sel, selain itu senyawa flavonoid dan antrakuinon menyebabkan denaturasi protein sel bakteri dan merusak membran sel secara permanen. Aloin merupakan stimulan katartika dengan meningkatkan tekanan otot polos pada dinding usus beberapa jam setelah masuk ke saluran cerna. Adapun mekanismenya masih belum jelas, diduga berpengaruh terhadap transport ion dalam sel di saluran cerna. Adanya senyawa-senyawa aktif inilah yang diasumsikan menjadi penyebab kerusakan organ midgut pada larva Ae. aegypti (Zhu et al., 2011; Mohammed et al., 2013).

Pengamatan ini sesuai dengan penelitian Abutaha dan Al-Mekhlafi dan Costa et al. menganalisa perubahan histopatologis pada Culex quinquefasciatus yang telah diberi ekstrak Melia azedarach dan Murraya paniculata di daerah midgut, terjadi pemisahan sel-sel epitel dari membran dasar, pembengkakan bagian apikal usus, penonjolan sel, vakuolisasi terutama sitoplasma, berkurangnya mikrovili dan sel epitel melimpah dalam lumen. Penelitian yang dilakukan pada Ae. aegypti yang diberi dengan ekstrak metanol Annona coriacea (Annonacea), ekstrak Carpparis cartilaginea, ekstrak Cassia siamea terjadi perubahan histopatologi yang serius, seperti vakuolisasi dari sitoplasma, hipertrofi sel epitel dan intinya, kerusakan mikrovili, disintegrasi sel dan pembentukan apikal dalam lumen usus (Abutaha dan AlMekhlafi, 2014; Costa et al., 2012). Emodin pada serangga melakukan aktivitas antifeedant dan mengalami kerusakan akibat menelan di midgut. Metabolit sekunder yang telah banyak dikembangkan sebagai larvasida merupakan senyawa toksik pada serangga yang memengaruhi fungsi fisiologi dengan berbagai cara yang berbeda (DeLiberto dan Werner, 2016).

Pemberian fraksi larut metanol pada larva mengakibatkan kerusakan pada organ midgut, mekanisme kematian pada larva tersebut belum diketahui secara pasti, karena fraksi larut metanol terdiri dari bermacammacam senyawa lain yang kemungkinan juga memiliki mekanisme yang berbeda. Penggunaan insektisida terutama larvasida dari tanaman dapat menghalangi perkembangan resistensi larva, karena tanaman tersebut terdiri dari beribu-ribu komponen dengan mekanisme aksi yang berbeda (metabolit sekunder, tripsin inhibitor dan lektin) (Promsiri et al., 2006).

\section{KESIMPULAN}

Fraksi larut metanol kulit lidah buaya menyebabkan kerusakan organ midgut larva Ae. aegypti. Kerusakan terjadi di daerah membran peritrofik, mikrovili dan sel epitel. Semakin tinggi dosis fraksi larut metanol, kerusakan yang terjadi semakin parah.

\section{DAFTAR PUSTAKA}

Abutaha N, Al-Mekhlafi A F. (2014). Evaluation of the Safe Use of Larvicidal Fraction of Capparis cartilaginea Decne Against Aedes caspius (Pallas) (Diptera: Culicidae). Larva Afr Entomol. 22: 838-46

Begum M. (2016). Histo-morphology of the larvae of Aedes aegypti (Diptera: culicidae). J Biodivers Conservation Bioresour Manag. 2 (1): 69-3

Clements A N. (1992). The biology of mosquitoes: development, nutrition and reproduction. Vol. 1. London: Chapman \& Hall. ISBN: 0412401800

Costa M S, Pinheiro D O, Serrao J E, Pereira M J B. (2012). Morphological Changes in the Midgut of Aedes aegypti L. (Diptera: Culicidae) Larvae Following Exposure to an Annona coriacea (Magnoliales: Annonaceae) Extract. Neotrop. Entomol. 41: 311-4

DeLiberto S T, Werner S J. (2016). Review of Anthraquinone Applications for Pest Management and Agricultural Crop Protection. Pest Management Science.72:1813-25 
Kementerian Kesehatan RI. (2018). Situasi Penyakit Demam Berdarah Di Indonesia Tahun 2017. Pusat Data dan Informasi Kementerian Kesehatan RI. Jakarta: Infodatin. ISSN: 24427659

Klowden M J. (2007). Physiological system in insects. 2nd ed. Burlington USA: Academic Press, Elsivier.

Kumar S, Yadav J P. (2014). Ethnobotanical and Pharmacological Properties of Aloe vera: A review. Academic J. 8 (48): 1387-98

Lu FC, Kacew S. (2002). Basic toxicology: Fundamentals, Target Organs, and Risk Assessment. 4th ed. New York: Hemisphere.

Maurya P, Mohan L, Sharma P, Srivastava C N. (2008).Larval susceptibility of Aloe barbadensis and Cannabis sativa against Culex quinquefasciatus, the Filariasis Vector. J Environ Biol. 29 (6): 941-43

Mohammed M M D, El-Souda S S, ElHallouty S M, Kobayashi N. (2013). Antiviral and cytotoxic activities of anthraquinones from Cassia roxburghii Linn. leaves. Kerva polonica. 59 (4): 33-44

Murini T. (2017). Penggunaan granul rimpang Lempuyang Gajah (Zingiber zerumbet (L) J. E. Smith terstandar Zerumbon sebagai larvisida Ae. aegypti (Diptera: Culicidae) [Disertasi]. Yogyakarta: Universitas Gadjah Mada

Nagaraju M, Ramulla S, Murthy N Y S. (2011). Extraction and Preliminary Analysis of Aloin Obtained from Aloe barbadensis Miller. Asian J Chem. 23 (6): 2421-3

Promsiri S, Naksathit A, Kruatrachue M, Tharava U. (2006). Evaluations of larvicidal activity of medicinal plant extracts to Aedes aegypti (Diptera:
Culicidae) and other effects on a non target fish. Insect Sci. 13: 179-88

Salvador-Neto O, Gomes S A, Soares A R, da Silva M F L, Samuels R I, da Fonseca $\mathrm{R} N$, et al. (2016).Larvicidal Potential of the Sesquiterpene Halogenated (+) -Obtusol, Isolated from the Alga Laurencia dendroidea J. Agardh (Ceramiales: Rhodomelaceae), Against the Dengue Vector Mosquito Aedes aegypti (Linnaeus) (Diptera: Culicidae). Mar Drugs. 14 (20): 1-14

Scudeler E L, Padovani C R, Santos D C D. (2014). Effectsof Neem Oil (Azhadirachta indica A. Juss) on the Replacement of the Midgut Epithelium in the Lacewing Ceraeochrysa claveri during Larvalpupal Metamorphosis. Acta Histochem. 116: 771-80

Subramaniam J, Kovendan K., Kumar P M, Murugan K., Walton W. (2012). Mosquito larvicidal activity of Aloe vera (Family: Liliaceae) leaf extract and Bacillus sphaericus, against Chikungunya vector, Aedes aegypti. Saudi J Bio Sciences. 1-7

WHO. (2014). Dengue and Severe Dengue. Geneva:World Health Organization.

WHO. (2005). Guidelines for laboratory and field testing of mosquito larvicides. Geneva: World Health Organization, Communicable Disease Control, Prevention and Eradication, WHO Pesticide Evaluation Scheme.

Zhu J. (2008). Mosquito Larvacidal Activity of Botanical-Based Mosquito Repellents. J AM Mosq Control Assoc. 24 (1): 161-8

Zhu Z Z, Ma K J, Ran X, Zhang H, Zheng C J, Han T, et al. (2011). Analgesic, anti-inflammatory and antipyretic activities of the petroleum ether fraction from the ethanol extract of Desmodium podocarpum. $J$ Ethnopharm. 133: 1126-31 